\title{
Physical Properties of an Alfisol Under Biofuel Crops in Ohio
}

\author{
Catherine Bonin* and Rattan Lal ${ }^{\#}$
}

\author{
Carbon Management and Sequestration Center, The Ohio State Univ., 210 Kottman Hall, 2021 Coffey Rd., \\ Columbus, $\mathrm{OH}, 43210$, USA
}

\begin{abstract}
There is an increasing need to develop renewable energy sources from biofuel crops to replace fossil fuels. Biofuel crops may also enhance ecosystem functions such as soil quality, water availability, and nutrient reserves. Therefore, the effects of four biofuel crops (corn (Zea mays), switchgrass (Panicum virgatum), indiangrass (Sorghastrum nutans) and willow (Salix spp.) were evaluated on soil quality at three sites in Ohio to assess the effects of crop species on soil bulk density $\left(\rho_{b}\right)$, soil moisture characteristics (SMC), water stable aggregate distribution (WSA), and aggregate tensile strength (TS) to $40 \mathrm{~cm}$ depth. Overall, results were site-specific, with most differences occurring for the clayey soil at the Northwest site. At the Jackson site, soil in the $0-10 \mathrm{~cm}$ layer under switchgrass had a higher moisture content $(\theta)$ between 0 and $100 \mathrm{kPa}$ than that under indiangrass. At the Western site, $\theta$ under corn at $1500 \mathrm{kPa}$ was higher at 30-40 $\mathrm{cm}$ depth. At the Northwest site, soils under corn in the $0-10 \mathrm{~cm}$ depth tended to have the lowest $\theta$ at 0 and $3 \mathrm{kPa}$, while soils under switchgrass and willow had 50\% more large macroaggregates and fewer small microaggregates than that under corn. Soil TS in the $0-10 \mathrm{~cm}$ depth under corn was nearly $160 \%$ more than that under other perennial crops. These results suggest that management of perennial biofuel crops can improve soil physical quality. Changes over seven years occur first in the surface soil layers, but further differences may evolve in subsoil layers with increase in time.
\end{abstract}

Keywords: Soil quality, biofuel feedstock, tensile strength, water stable aggregate, bioenergy.

\section{INTRODUCTION}

The search for renewable and sustainable energy sources has been driven by the rising cost of fossil fuel, as well as increasing atmospheric greenhouse gas (GHG) concentrations and the threat of climate change and environmental degradation. In the US, corn grain is the primary crop for ethanol production, with over 52 billion liters of corn grain ethanol produced in 2011 [1]. However, the Energy Independence and Security Act of 2007 (EISA) has capped corn grain contributions and requires that other crops be increasingly used to supply ethanol, such as perennial grasses, trees, algae, etc.

Until recently, biofuel research has focused mainly on comparing bioenergy yields of different feedstocks and potential carbon (C) sequestration by biofuel crops. The implementation of life-cycle assessments (LCA) has helped to quantify and contrast the energy and GHG balances of crop options by providing estimates of energy and GHG costs for crop and biofuel production, as well as biofuel consumption. Although LCAs provide a method of determining crop costs and benefits, results have been equivocal, even within the same crop due to factors such as uncertainties in quantification and by-product allocation methods [2]. Even with these uncertainties, most LCAs suggest that

\footnotetext{
*Address corresponding to this author at the Carbon Management and Sequestration Center, The Ohio State Univ., 210 Kottman Hall, 2021 Coffey Rd., Columbus, OH, 43210, USA; Tel: (608) 335-6750; Fax: (614) 292-7432; E-mail: bonin.8@ osu.edu

${ }^{\#}$ Co-Author. Rattan Lal: E-mail: lal.1@osu.edu
}

corn and other annual crops have a lower net energy balance (NEB; the ratio of energy produced to energy used), and a lower GHG balance than perennial species such as grasses and trees [3-6].

What is less understood is how managing for different bioenergy crops may affect soil physical properties. Soil is a vital resource whose quality and ecosystem services can be strongly influenced by vegetation and management practices. Biofuels and management practices can improve soil physical properties such as bulk density $\left(\rho_{b}\right)$, porosity $(\varphi)$, soil strength, and aggregate stability [7]. Improvements in soil quality may enhance resource use efficiency, maintain biomass productivity, reduce risks of accelerated erosion and runoff, increase soil water retention, improve aggregate stability, as well as sequester soil organic carbon (SOC) [8,9]. For example, aggregation influences soil structure, which is an important factor in maintaining soil quality and sustaining agricultural productivity [10]. Likewise, soil strength impacts root elongation, seedling emergence, and plant growth. In this manner biofuel crops may augment multiple ecosystem services: produce energy, reduce atmospheric GHG release, and improve soil quality.

Plant growth and potential ethanol yields are also affected by soil hydrological properties. Adequate moisture must be retained in the soil for water uptake by roots, and water stress can elicit a variety of plant responses that reduce photosynthesis, lower transpiration rates, and can decrease agronomic yields 
[11,12]. Water is a resource that will become increasingly limited from increases in anthropogenic demands and global climate change [13]. Soil moisture properties are correlated with soil texture, $\rho_{\mathrm{b}}$, and soil organic matter (SOM) content [14]. Enhancing soil quality to increase soil moisture and plant available water (PAW) may reduce irrigation needs and sustain biofuel crop production.

Plant lifeform and chemical composition can also affect nutrient cycling and $C$ dynamics in soil $[15,16]$. Longer-lived, deeply rooted perennial systems may also store more SOC in deeper sub-soil than shorterlived and shallow-rooted annual crops could [17]. Texture can also play a role in affecting soil properties, but when grasslands, forests, and cropland have similar soil textures, the perennial ecosystems can have higher SOM concentrations, lower soil $\rho_{b}$, more water stable soil aggregates (WSA), and greater PAW capacity [18]. Finally, soil properties change slowly over time, such that differences may take years or decades to appear $[19,20]$, although in some cases positive changes in SOC to $150 \mathrm{~cm}$ depth have been observed within nine years under both switchgrass (Panicum virgatum) and corn (Zea mays) [21].

Each biofuel crop may have different effects on soil characteristics based on plant attributes such as life habit, root mass and rooting distribution, and plant tissue composition. Annual crops, such as corn, may have a shorter growing period than perennials. Annuals also require replanting each year, which could further impact soil properties. In contrast, perennial grasses and trees can have extensive and deep root systems. Up to $80 \%$ of switchgrass biomass may occur belowground [22]. Switchgrass and willow (Salix spp.) produce more fine root biomass than corn $\left(8.8 \mathrm{Mg} \mathrm{ha}^{-1}\right.$ and $5.8 \mathrm{Mg} \mathrm{ha}^{-1}$, respectively, versus $0.9 \mathrm{Mg} \mathrm{ha}^{-1}$ for corn), and have a greater proportion of roots below 35 $\mathrm{cm}$ [23]. Likewise, soils under grass and forest buffers have lower $\rho_{b}$, more porosity, and can potentially store more water than soils under cropland [24]. Rooting properties can also lower soil tensile strength (TS) under switchgrass [25].

The objective of this research was to examine soil properties under four biofuel crops, namely corn, willow, switchgrass, and indiangrass (Sorghastrum nutans), and compare how the soils under each crop treatment have differentiated in the seven years since establishment of this biofuel crop experiment. The hypothesis tested was that soil under the grass and tree species would have better soil quality as indicated by lower $\rho_{b}$, higher WSA, lower TS, and would have favorable soil moisture retention characteristics with high PAW.

\section{MATERIALS AND METHODS}

The study was conducted at three Ohio Agricultural Research and Development Center (OARDC) sites: the

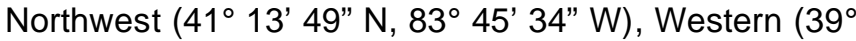
$\left.51^{\prime} 21^{\prime \prime} \mathrm{N}, 83^{\circ} 40^{\prime} 40^{\prime \prime} \mathrm{W}\right)$, and Jackson (39० $1^{\prime} 39^{\prime \prime} \mathrm{N}$, $82^{\circ} 36^{\prime} 17^{\prime \prime} \mathrm{W}$ ) branches (Table 1). The soil series at the Northwest site are Hoytville silty clay loam and Hoytville clay loam (Fine, illitic, mesic Mollic Epiaqualfs). At the Western site, soils are primarily Kokomo silty clay loam (fine, mixed, superactive, mesic Typic Argiaquoll) and Strawn-Crosby complex (fineloamy, mixed, active, mesic Typic Hapludalf; fine, mixed, active, mesic Aeric Epiaqualf). In Jackson, the soil series are Rarden-Wharton silt loams (Fine, mixed, active, mesic Aquultic Hapludalfs, Fine-loamy, mixed, active, mesic Aquic Hapludults) and Shelocta-Rarden association, steep (Fine-loamy, mixed, active, mesic Typic Hapludults, Fine, mixed, active, mesic Aquultic Hapludalfs) $[26,27]$.

Table 1: Historical Site Characteristics and Prior Land Use of the Three Sites in Ohio where the Biofuel Experiment was Established

\begin{tabular}{|c|c|c|c|c|c|}
\hline Site & Location & Temperature $\left({ }^{\circ} \mathrm{C}\right)$ & Precipitation (cm) & Prior land use & Crops \\
\hline Northwest & $\begin{array}{l}41^{\circ} 13^{\prime} 49^{\prime \prime} \mathrm{N} \\
83^{\circ} 45^{\prime} 34^{\prime \prime} \mathrm{W}\end{array}$ & 9.9 & 85.6 & Sod & $\begin{array}{c}\text { Switchgrass } \\
\text { Corn } \\
\text { Willow }\end{array}$ \\
\hline Western & $\begin{array}{l}39^{\circ} 51^{\prime} 21^{\prime \prime} \mathrm{N} \\
83^{\circ} 40^{\prime} 40^{\prime \prime} \mathrm{W}\end{array}$ & 10.9 & 105.7 & Corn-soybean rotation & $\begin{array}{c}\text { Switchgrass } \\
\text { Indiangrass } \\
\text { Corn } \\
\text { Willow }\end{array}$ \\
\hline Jackson & $\begin{array}{c}39^{\circ} 1 \text { ' } 39^{\prime \prime} \mathrm{N} \\
82^{\circ} 36^{\prime} 17^{\prime \prime} \mathrm{W}\end{array}$ & 11.4 & 109.2 & Forage grasses & $\begin{array}{l}\text { Switchgrass } \\
\text { Indiangrass }\end{array}$ \\
\hline
\end{tabular}


Switchgrass, indiangrass, willow, and no-till (NT) corn plots were established in spring 2004. The Western site was the only location where all four biofuel crops were planted (Table 1). Soils were plowed before sowing or planting to facilitate stand establishment. Corn and switchgrass plots were $6 \times 6$ $\mathrm{m}$, while willow plots were $12 \times 6 \mathrm{~m}$, and all treatments were replicated four times, with the exception of indiangrass at the Western site (replicated twice). Willow seedlings were planted at a rate of 2400 trees $\mathrm{ha}^{-1}$, in six rows of three trees per plot, and $28 \mathrm{~g} \mathrm{~N}$ was spread in a $15-\mathrm{cm}$ circle around each tree seedling $(67$ $\left.\mathrm{kg} \mathrm{N} \mathrm{ha}{ }^{-1}\right)$. In spring of 2007 and 2008, $69 \mathrm{~g} \mathrm{~N}(168 \mathrm{~kg}$ $\left.\mathrm{N} \mathrm{ha}{ }^{-1}\right)$ and $23 \mathrm{~g} \mathrm{P}\left(56 \mathrm{~kg} \mathrm{P} \mathrm{ha}^{-1}\right)$ were applied around each tree. The NT corn was sidedressed with $110 \mathrm{~kg} \mathrm{~N}$ $\mathrm{ha}^{-1}$ annually. Willow trees have not been harvested since establishment.

Switchgrass was sown into plots at a seeding rate of $11.2 \mathrm{~kg}$ pure live seed ha- ${ }^{-1}$, with $56 \mathrm{~kg} \mathrm{~N}^{-1}$ applied at establishment. No other fertilizers were applied to switchgrass plots until initiation of a fertilizer experiment in 2008 and 2009. For these two years, each switchgrass plot was divided into four quarters and sub-plot received one of four rates of $\mathrm{N}$ fertilizer. The current analysis was conducted on sub-plots that received $50 \mathrm{~kg} \mathrm{~N} \mathrm{ha}^{-1}$ annually for the two years, as this application rate approximates the amount of $\mathrm{N}$ that switchgrass removes annually from soils at this site [28]. Each year after establishment, switchgrass plots and indiangrass were harvested at $\sim 15 \mathrm{~cm}$ stubble height in late fall, and the cut biomass was removed.

\section{Soil Sampling and Analysis}

Bulk samples were collected using a shovel in the summer of 2011 from plots at all three sites to 0 - to 10$\mathrm{cm}$ and $10-$ to $20-\mathrm{cm}$ depths. Soil samples were collected between rows in corn and willow plots, and randomly within the grass plots. Intact soil cores were also collected with a core sampler at four $(0-$ to $10-\mathrm{cm}$, 10-to $20-\mathrm{cm}, 20$-to $30-\mathrm{cm}$, and $30-$ to $40-\mathrm{cm}$ ) depths. Due to the availability of cores, one core size was used at the Western site, and a slightly larger core size was used at the Northwest and Jackson sites. Cores collected at the Western site were $4.75 \mathrm{~cm}$ in diameter by $5 \mathrm{~cm}$ deep, while those collected at the Northwest and Jackson sites were $5.35 \mathrm{~cm}$ in diameter by $6 \mathrm{~cm}$ deep. All cores collected within a site were the same size, allowing for comparison among crop treatments within sites. Bulk samples were air dried and passed through 8- and 4.75-mm mesh screens to collect soil aggregates with sizes between 4.75- and $8-\mathrm{mm}$. Cores were trimmed, wrapped in plastic and stored at $4{ }^{\circ} \mathrm{C}$ pending analysis.

\section{Bulk Density and Soil Moisture Characteristics}

Soil $\rho_{b}$ was calculated for each of the four depths using the core method [29]. Since cores were kept intact for soil moisture characteristic (SMC) analysis, a portion of the core trimmings was oven-dried at $105^{\circ} \mathrm{C}$ for 48-72 hours and used to estimate oven-dry core weight. The $\rho_{b}$ was calculated by dividing oven-dry soil weight by its volume.

After cores were weighed, a piece of cheesecloth was fixed to the bottom of each core using a rubber band. Cores were completely saturated for 2-3 days used to assess SMC:

$$
\theta=\mathrm{f}(\Phi)
$$

where $\theta$ is volumetric moisture content $\left(\theta=w^{*} \rho_{b} / \rho_{w}\right.$, where $w$ is the gravimetric water content and $\rho_{w}$ is the density of water) and $\Phi$ is soil moisture potential $(\mathrm{kPa})$ measured using both the tension table and pressure plate extractors [30]. The SMC were calculated by measuring soil water retention at $0,3,6,33,100$, and $1500 \mathrm{kPa}$. Intact soil cores were used for the first five $\Phi$, while sieved soils were used at $1500 \mathrm{kPa} 2 \mathrm{~mm}$. Field water capacity (FWC) and the permanent wilting point (PWP) were computed as $\theta$ at $33 \mathrm{kPa}$ and 1500 $\mathrm{kPa}$, respectively. Plant available water (PAW) was calculated as the difference between FWC and PWP. The $\theta$ held by spore size classes was calculated as the difference in $\theta$ between two pore sizes. Pore size was determined based on capillary rise [31]:

$$
r=0.15 / h
$$

where $r$ is the radius of pores $(\mathrm{cm})$ and $h$ is the height of the water column or $\Phi(\mathrm{cm})$. Six pore size classes were defined: $>300 \mu \mathrm{m}, 50-300 \mu \mathrm{m}, 9-50 \mu \mathrm{m}, 3-9 \mu \mathrm{m}$, $0.02-3 \mu \mathrm{m}$, and $<0.02 \mu \mathrm{m}$ in pore diameter.

\section{Water Stable Aggregates}

Air-dry aggregates from bulk soils were used to measure size distribution and percent of WSA using the wet sieving method [32]. Approximately $50 \mathrm{~g}$ of aggregates $(4.75-8 \mathrm{~mm})$ were placed into a Yoder apparatus containing five nested sieves of $4.75,2.00$, $1.00,0.425$, and $0.162 \mathrm{~mm}$ diameter [33]. Aggregates were slowly wetted by capillary action for 15 minutes and then oscillated mechanically for 30 minutes at 60 oscillations $\mathrm{min}^{-1}$. Soil aggregates retained on each 
sieve were transferred to beakers and dried at $40^{\circ} \mathrm{C}$ for 2 days, and weighed. Soil passing through the 0.162 $\mathrm{mm}$ sieve was also collected, dried, and weighed. The $\%$ WSA was calculated on six size classes: $>4.75 \mathrm{~mm}$, 4.75-2.00 mm, $1.00-2.00 \mathrm{~mm}, 0.425-1.00 \mathrm{~mm}, 0.162$ $\mathrm{mm}-0.425 \mathrm{~mm}$, and $<0.162 \mathrm{~mm}$. The data were used to calculate the mean weight diameter (MWD) according to Youker and McGuinness [34].

\section{Aggregate Tensile Strength}

The TS for each of the $0-10 \mathrm{~cm}$ and $10-20 \mathrm{~cm}$ depths were tested in a crushing apparatus similar to that described by Horn and Dexter [35]. Five aggregates $(4.75-8 \mathrm{~mm})$ were selected from each plot and depth and tested in using a crushing test (indirect tension). Using the method by Dexter and Kroesbergen [36], three diameters were taken for each aggregate to calculate the average diameter $\left(D_{\text {agg }}\right)$. The TS was calculated as:

$$
\mathrm{TS}=0.576^{\star}\left(\mathrm{F} / \mathrm{D}_{\mathrm{agg}}{ }^{2}\right)
$$

where $F$ is the force needed to rupture the aggregate measured by the crushing apparatus [37].

\section{Soil Texture and $\mathrm{pH}$}

Soil texture and $\mathrm{pH}$ were measured for $0-10,10-20$, 20-30, and 30-40 cm depths. Once SMC analyses were completed on the soil cores, the soil was air-dried and ground to pass through a 2-mm sieve. The particle size analysis (PSA) was determined by using the pipette method [38]. The $\mathrm{pH}$ was calculated by mixing
$10 \mathrm{~g}$ of soil with $10 \mathrm{~mL}$ distilled water (1:1 ratio). Samples were vortexed for one minute, then allowed to rest for one hour. After the rest period, samples were quickly vortexed again and $\mathrm{pH}$ was measured with a glass electrode.

\section{Statistical Analysis}

Soils from each site were analyzed separately using PROC MIXED of SAS (Version 9.2, SAS Institute, Cary, NC) [39]. Biofuel crop and depth were treated as fixed variables and replication as a random variable. For TS, the five aggregates measured for each crop and depth were treated as subsamples. Responses for each treatment were separated using the test for least significant differences (LSD), with $\alpha=0.05$.

\section{RESULTS}

The three sites differed in climate, soil texture, soil $\mathrm{pH}$, and soil $\rho_{\mathrm{b}}$ (Tables 1 and 2). Both precipitation and temperature increased from the northern to the southern research stations. The Northwest site, which had the highest clay content, also had the highest $\mathrm{pH}$. Surface soil $\rho_{b}$ was the highest at the Western site and the lowest at the Jackson site.

\section{Bulk Density}

Although the size of cores collected varied, which could impact $\rho_{b}$ measurements, results were similar to those calculated by Jung [28] in 2008 and 2009, suggesting that different core sizes had little effect on variations in $\rho_{b}$. While soil $\rho_{b}$ was affected by site and

Table 2: Soil Properties for the 0-10, 10-20, 20-30, and 30-40 cm Depths Under Biofuel Crops at Three Sites in Ohio

\begin{tabular}{|c|c|c|c|c|c|c|c|}
\hline Site & Depth (cm) & Sand $(\%)$ & Silt (\%) & Clay (\%) & Texture & $\mathrm{pH}$ & Bulk density $\left(\mathrm{Mg} \mathrm{m}^{-3}\right)$ \\
\hline \multirow[t]{4}{*}{ Northwest } & $0-10$ & 21.1 & 42.5 & 36.5 & Clay Loam & 6.71 & 1.39 \\
\hline & $10-20$ & 20.2 & 42.1 & 37.8 & Clay Loam & 6.93 & 1.51 \\
\hline & $20-30$ & 20.4 & 40.6 & 39.1 & Clay Loam & 7.07 & 1.55 \\
\hline & $30-40$ & 19.0 & 39.0 & 42.0 & Clay & 7.30 & 1.58 \\
\hline \multirow[t]{4}{*}{ Western } & $0-10$ & 24.1 & 58.8 & 17.2 & Silt Loam & 5.42 & 1.47 \\
\hline & $10-20$ & 23.6 & 57.8 & 18.6 & Silt Loam & 5.49 & 1.66 \\
\hline & $20-30$ & 23.1 & 58.5 & 18.4 & Silt Loam & 5.38 & 1.65 \\
\hline & $30-40$ & 22.2 & 57.0 & 20.8 & Silt Loam & 5.71 & 1.64 \\
\hline \multirow[t]{4}{*}{ Jackson } & $0-10$ & 18.7 & 62.7 & 18.6 & Silt Loam & 6.54 & 1.29 \\
\hline & $10-20$ & 16.5 & 63.5 & 20.1 & Silt Loam & 6.63 & 1.48 \\
\hline & $20-30$ & 13.5 & 62.1 & 24.5 & Silt Loam & 6.67 & 1.53 \\
\hline & $30-40$ & 12.2 & 59.0 & 28.8 & Silty Clay Loam & 6.48 & 1.60 \\
\hline
\end{tabular}


soil depth, biofuel crop species had little effect. Where differences did occur, it was in the surface layer only. At the Jackson site, soil in the $0-10 \mathrm{~cm}$ depth under switchgrass had a lower $\rho_{b}$ compared to that under indiangrass, at $1.23 \mathrm{Mg} \mathrm{m}^{-3}$ versus $1.35 \mathrm{Mg} \mathrm{m}^{-3}$, respectively $(P=0.0084)$. At the Northwest site, soil $\rho_{b}$ in the $0-10 \mathrm{~cm}$ layer tended to be higher under corn $\left(1.49 \mathrm{Mg} \mathrm{m}^{-3}\right)$ than under switchgrass $\left(1.33 \mathrm{Mg} \mathrm{m}^{-3}\right)$, with soil $\rho_{\mathrm{b}}$ under willow $\left(1.35 \mathrm{Mg} \mathrm{m} \mathrm{m}^{-3}\right)$ being intermediate of the two crops $(P=0.0588)$.
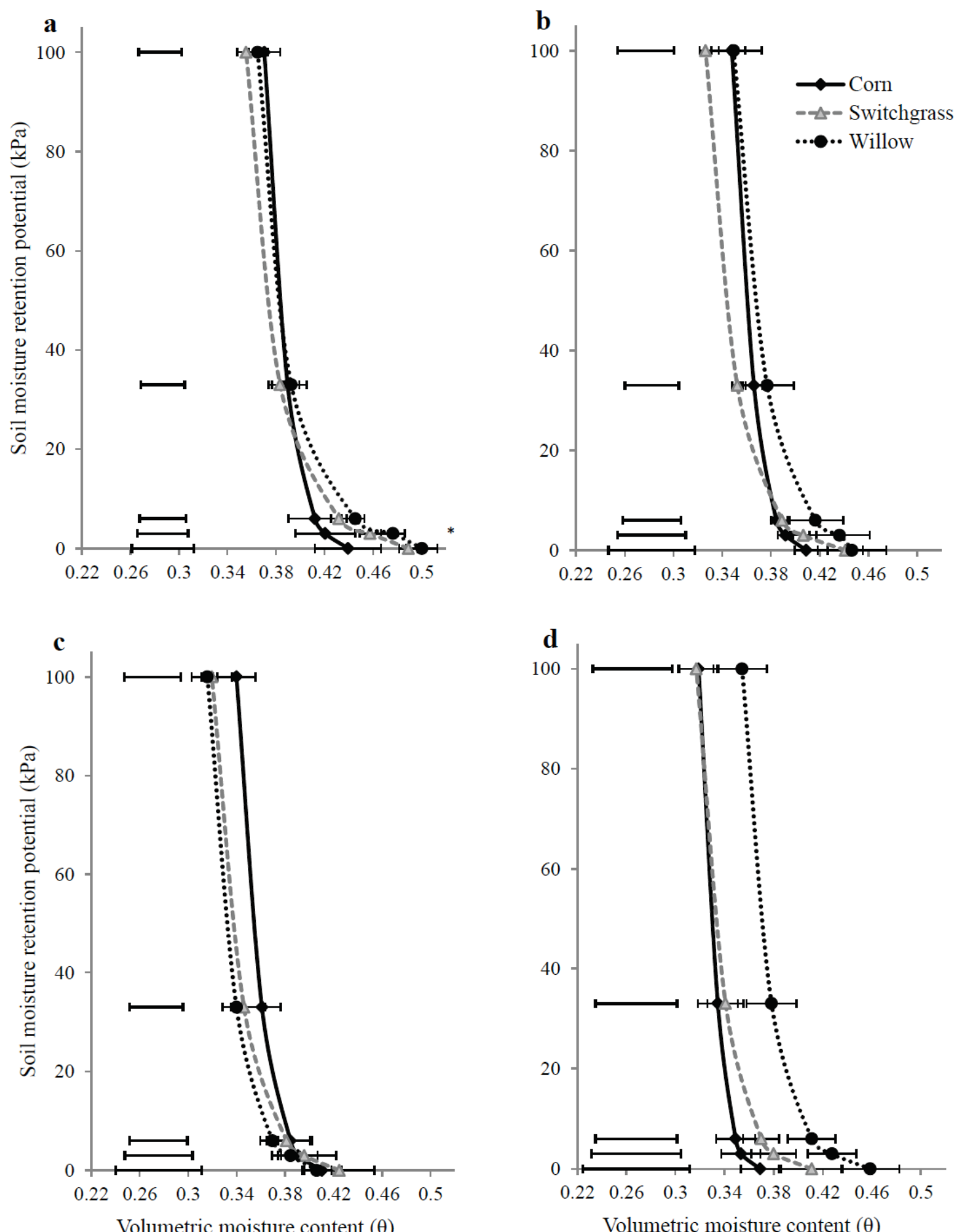

Figure 1: Soil moisture characteristic curves under biofuel crops at four depths at the Northwest site (mean \pm s.e. for each soil moisture potential $\Phi)$. The bars to the left of the curves indicate the LSD $(0.05)$ values for each $\Phi$ within each depth. A "*" indicates where the volumetric water content $(\theta)$ at the particular soil moisture retention potential under biofuel crops differs significantly $(P<0.05)$. 


\section{Soil Moisture Characteristics}

Differences in SMCs occurred primarily at the Jackson site, and in the $0-10 \mathrm{~cm}$ soil depth (Figures 13). At this depth, soil under switchgrass held more moisture than that under indiangrass for all $\Phi$ except
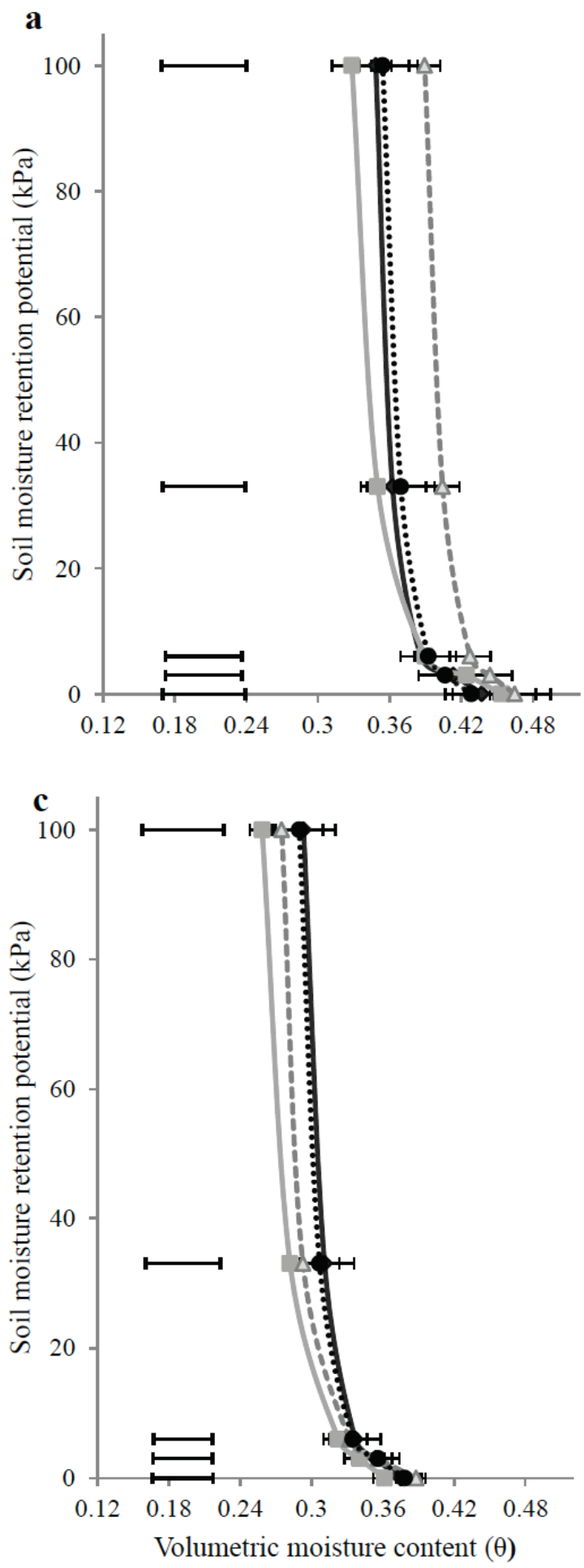

$1500 \mathrm{kPa}(\mathrm{P}<0.015$ at each $\Phi)$. In addition, Jackson soils under switchgrass tended to have a higher PAW than that under indiangrass $(P=0.0559)$. In the 0 $10 \mathrm{~cm}$ depth at the Northwest site, corn tended to have the lowest $\theta$ and those under willow the highest $\theta$ at 0 $\mathrm{kPa}$ and $3 \mathrm{kPa}(\mathrm{P}=0.0576$ and $\mathrm{P}=0.0437$,
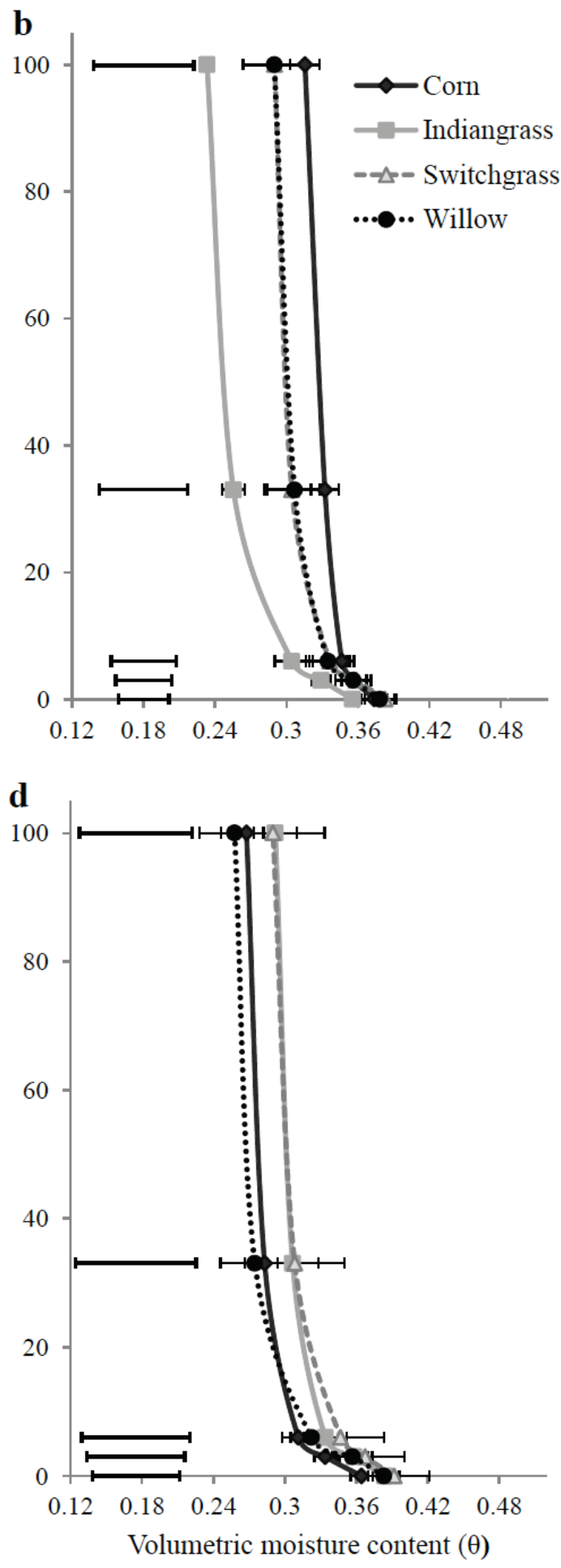

Figure 2: Soil moisture characteristic curves under biofuel crops at four depths at the Western site (mean \pm s.e. for each soil moisture potential $\Phi)$. The bars to the left of the curves indicate the LSD $(0.05)$ values for each $\Phi$ within each depth. 

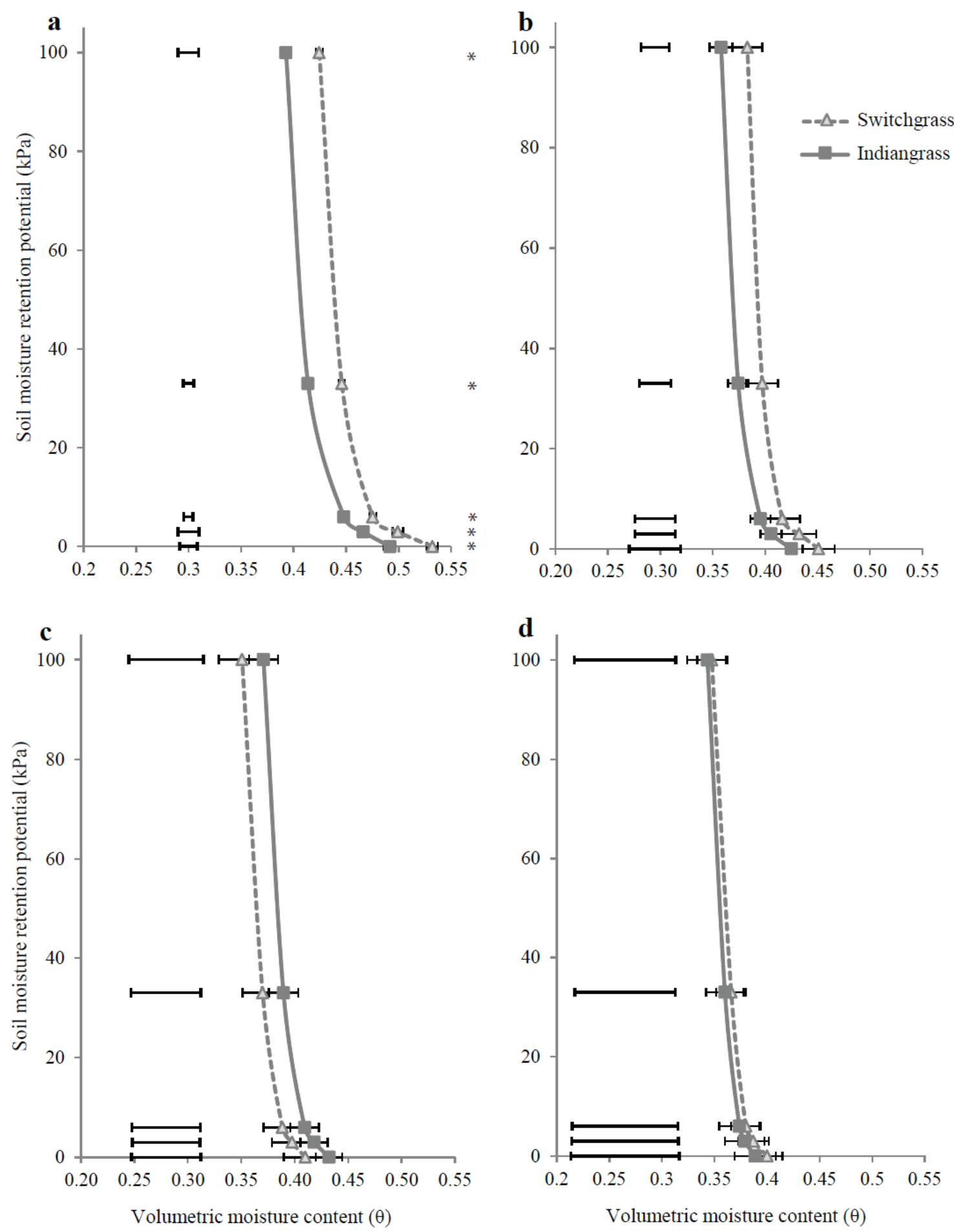

Figure 3: Soil moisture characteristic curves under biofuel crops at four depths at the Jackson site (mean \pm s.e. for each soil moisture potential $\Phi)$. The bars to the left of the curves indicate the LSD $(0.05)$ values for each $\Phi$ within each depth. A "*" indicates where the volumetric water content $(\theta)$ at the particular soil moisture retention potential under biofuel crops differs significantly $(\mathrm{P}<0.05)$.

respectively), but there were no other differences in SMCs. At the Western site, soil under corn tended to have higher $\theta$ at $1500 \mathrm{kPa}$ than that under other biofuel crops, but this was only significant at the $30-40 \mathrm{~cm}$ depth $(P=0.0051)$.
Evaluation of $\theta$ held by pore size classes produced similar results (Figure 4). At the Northwest site, the primary differences occurred among pores between 3 and $300 \mu \mathrm{m}$. Where differences were present, soil under willow held the most water within a pore size 


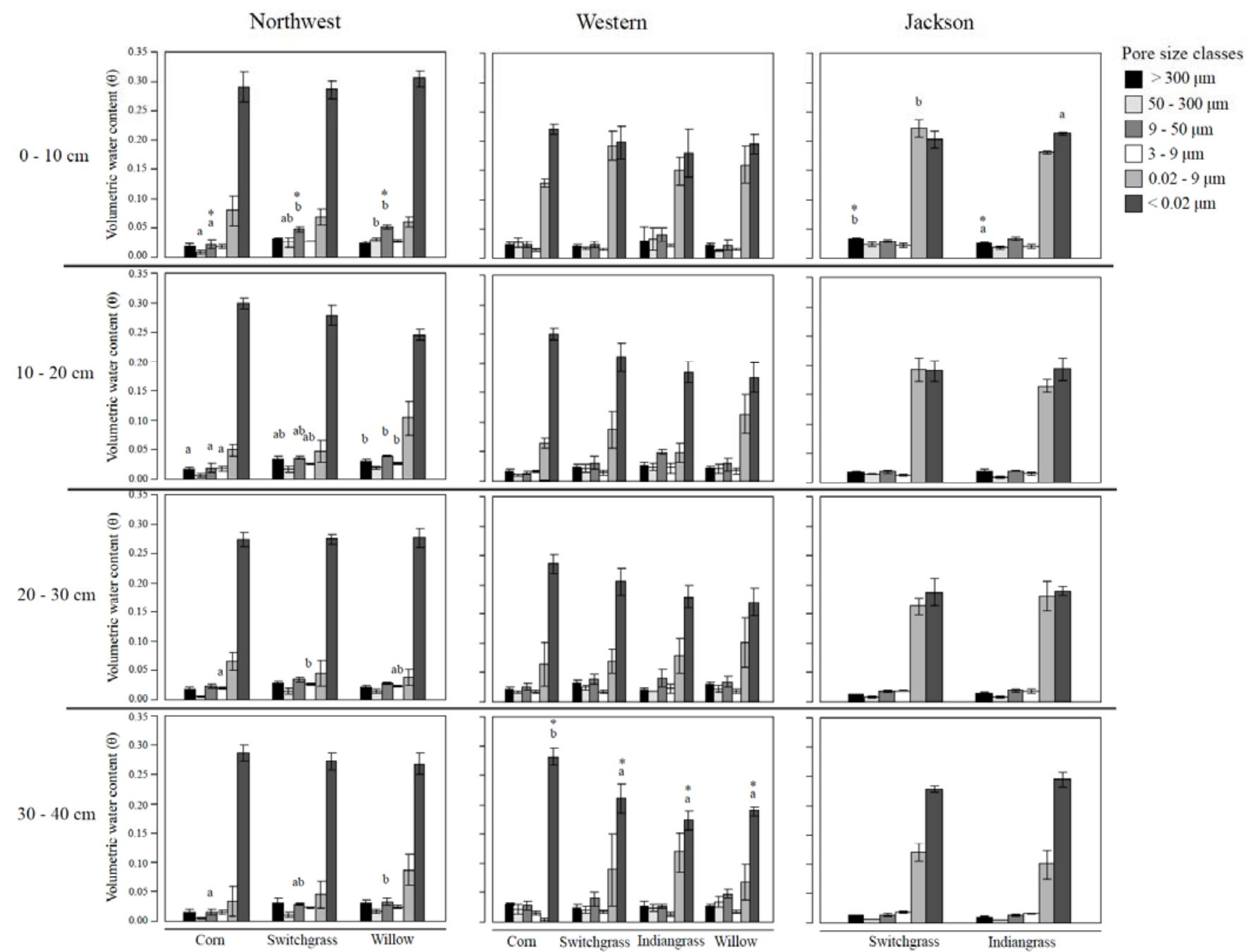

Figure 4: Soil moisture content $(\theta)$ held within size pore size classes under biofuel crops at four soil depths in three sites in Ohio. Different letters signify where $\theta$ for the particular pore size class differs among soils under biofuel crops at $P<0.10$. Letters with a "*” above them signify that the difference is significant at $\mathrm{P}<0.05$.

class, and that under corn the least, with soil under switchgrass being intermediate. One exception was in the $10-20 \mathrm{~cm}$ soil layer, where soil under corn tended to have a higher $\theta$ than that under willow ( $P=0.0875)$. The only difference at the Western site was in the smallest pore class $(<0.02 \mu \mathrm{m})$, where soil under corn in the 30-40 cm layer held more water than those under the grasses or willow $(P=0.0051)$. At the Jackson site, soil under switchgrass and indiangrass tended to have similar $\theta$, with two exceptions in the top $0-10 \mathrm{~cm}$ soil depth. At this depth, large pores $(>300 \mu \mathrm{m})$ in soils under switchgrass had a higher $\theta$ that those under indiangrass $(p=0.0177)$, which was also a trend for pores 0.2 to $3 \mu \mathrm{m}(p=0.0609)$.

\section{Water Stable Aggregates and Tensile Strength}

The size of WSA generally decreased with increase in depth at all three sites. The only differences in
\%WSA and MWD occurred at the Northwest site, where soils under switchgrass and willow had more large macroaggregates than those under corn (Table 3). In comparison with soil under corn, those under the two perennial crops had $50 \%$ more macroaggregates > $4.75 \mathrm{~mm}$, but $600 \%$ more microaggregates $<0.162 \mathrm{~mm}$ in the $0-10 \mathrm{~cm}$ depth. Similarly, the $10-20 \mathrm{~cm}$ depth showed that soil under corn had a greater proportion of small aggregates. The MWD of aggregates under switchgrass and willow was nearly $30 \%$ higher than that under corn at the $0-10 \mathrm{~cm}$ depth $(P=0.0272)$, with a similar trend of lower MWD under corn at the 10-20 cm depth $(P=0.0695)$.

The soils at the Northwest site has the largest aggregate TS and were 50 to $100 \%$ stronger than those under the same biofuel crop at the other two sites. Soil TS was similar under crops at the Western 
Table 3: Distribution of Water-Stable Aggregates (WSA, by \%) and Mean Weight Diameter (MWD, mm) in the 0-10 and 10-20 cm Soil Depths Under Four Crop Species at Three Sites in Ohio

\begin{tabular}{|c|c|c|c|c|c|c|c|c|c|c|c|c|c|c|}
\hline \multicolumn{15}{|c|}{ Northwest site } \\
\hline \multicolumn{7}{|c|}{$0-10 \mathrm{~cm}$ depth } & \multicolumn{8}{|c|}{$10-20 \mathrm{~cm}$ depth } \\
\hline Cropt & $\begin{array}{c}>4.75 \\
\mathrm{~mm}\end{array}$ & $\begin{array}{l}4.75- \\
2.00 \\
\mathrm{~mm}\end{array}$ & $\begin{array}{l}1.00- \\
2.00 \\
\mathrm{~mm}\end{array}$ & $\begin{array}{c}0.425- \\
1.00 \\
\mathrm{~mm}\end{array}$ & $\begin{array}{c}0.162 \\
-0.425 \\
\mathrm{~mm}\end{array}$ & $\begin{array}{c}<0.162 \\
\mathrm{~mm}\end{array}$ & MWD & $\begin{array}{c}>4.75 \\
\mathrm{~mm}\end{array}$ & $\begin{array}{l}4.75- \\
2.00 \\
\mathrm{~mm}\end{array}$ & $\begin{array}{l}1.00- \\
2.00 \\
\mathrm{~mm}\end{array}$ & $\begin{array}{c}0.425- \\
1.00 \\
\mathrm{~mm}\end{array}$ & $\begin{array}{c}0.162 \\
-0.425 \\
\mathrm{~mm}\end{array}$ & $\begin{array}{c}<0.162 \\
\mathrm{~mm}\end{array}$ & MWD \\
\hline Corn & $61.7^{\mathrm{a}}$ & 16.3 & $8.7^{b}$ & $5.9^{b}$ & $3.5^{\mathrm{b}}$ & $3.9^{b}$ & $4.67^{a}$ & 60.4 & 15.8 & $9.2^{b}$ & $6.2^{b}$ & $4.0^{b}$ & $4.3^{b}$ & 4.58 \\
\hline$S G \ddagger$ & $93.9^{b}$ & 4.0 & $0.8^{\mathrm{a}}$ & $0.5^{\mathrm{a}}$ & $0.4^{\mathrm{a}}$ & $0.5^{\mathrm{a}}$ & $6.13^{b}$ & 73.9 & 13.8 & $5.2^{\mathrm{a}}$ & $2.9^{a}$ & $1.9^{\mathrm{a}}$ & $2.3^{\mathrm{a}}$ & 5.28 \\
\hline Willow & $89.5^{b}$ & 6.6 & $1.6^{\mathrm{a}}$ & $0.9^{a}$ & $0.5^{\mathrm{a}}$ & $0.8^{\mathrm{a}}$ & $5.96^{b}$ & 78.0 & 11.9 & $4.2^{\mathrm{a}}$ & $2.6^{a}$ & $1.5^{\mathrm{a}}$ & $1.8^{\mathrm{a}}$ & 5.46 \\
\hline $\begin{array}{c}\mathrm{p}- \\
\text { value }\end{array}$ & 0.031 & 0.0734 & 0.015 & 0.0129 & 0.0235 & 0.0429 & 0.0272 & 0.145 & 0.7553 & 0.0422 & 0.0173 & 0.0028 & 0.0188 & 0.0695 \\
\hline \multicolumn{15}{|c|}{ Western site } \\
\hline Corn & 64.1 & 9.5 & 6.5 & 8.3 & 5.1 & 6.5 & 4.59 & 57.0 & 6.3 & 8.0 & 10.2 & 8.7 & 9.9 & 4.07 \\
\hline SG & 77.9 & 5.0 & 3.5 & 4.9 & 3.1 & 5.6 & 5.24 & 78.9 & 5.2 & 3.9 & 5.1 & 2.8 & 4.1 & 5.31 \\
\hline $\mathrm{IG}$ & 93.6 & 1.8 & 0.8 & 0.9 & 0.9 & 2.0 & 6.05 & 63.2 & 6.9 & 5.0 & 9.4 & 8.6 & 7.0 & 4.43 \\
\hline Willow & 84.9 & 6.2 & 2.3 & 1.9 & 1.5 & 3.3 & 5.67 & 57.6 & 7.9 & 6.7 & 10.8 & 9.4 & 7.5 & 4.15 \\
\hline $\begin{array}{c}\mathrm{p}- \\
\text { value }\end{array}$ & 0.3836 & 0.3938 & 0.3358 & 0.1267 & 0.1711 & 0.3395 & 0.3042 & 0.4178 & 0.6442 & 0.3481 & 0.3929 & 0.3959 & 0.6667 & 0.4179 \\
\hline \multicolumn{15}{|c|}{ Jackson site } \\
\hline SG & 71.3 & 11.3 & 6.4 & 5.9 & 2.2 & 2.9 & 5.12 & 57.5 & 12.0 & 8.4 & 8.7 & 5.7 & 7.7 & 4.13 \\
\hline$I G$ & 72.3 & 11.1 & 5.7 & 5.2 & 2.7 & 2.9 & 5.07 & 54.8 & 12.4 & 8.7 & 9.1 & 7.0 & 8.1 & 4.28 \\
\hline $\begin{array}{c}\mathrm{p}- \\
\text { value }\end{array}$ & 0.9274 & 0.9628 & 0.8361 & 0.824 & 0.6042 & 1.00 & 0.9205 & 0.6341 & 0.9198 & 1.00 & 0.8361 & 0.5791 & 0.8523 & 0.6785 \\
\hline
\end{tabular}

${ }^{\dagger}$ Means with different letters within a pore class and site are significantly different at $P<0.05$.

${ }^{\ddagger} S G$ : switchgrass; IG: indiangrass.

and Jackson sites. Overall, aggregate TS increased with increase in soil depth under biofuel crops. At both the Northwest and Western sites, soil in the $0-10 \mathrm{~cm}$ depth under corn had the largest aggregate TS, compared with that under other biofuel crops (Table 4). Soil aggregate TS under corn increased nearly $160 \%$, compared to aggregates under switchgrass and willow. There were no differences in TS at the Jackson site, or at the $10-20 \mathrm{~cm}$ soil depth at any of the three sites.

\section{DISCUSSION}

Soil aggregation and TS are integral parts of soil structure, and may impact soil porosity, stabilization and protection of SOM, and microfaunal habitat [40]. Seven years since establishment of biofuel crops, some differences in soil physical and hydrological properties were observed, primarily in the top $10 \mathrm{~cm}$ layer. In most instances, each site has distinct soil physical properties due to soil texture, site history, and climate: compared to the Jackson and Western sites, the Northwest site has the largest $\mathrm{pH}$ and soils with the highest TS, larger MWD and WSA. Differences among soils under biofuel crops occurred most often at the
Northwest site, which had clayey soils, cooler temperatures, and less precipitation than the other two locations, suggesting that soil and environmental conditions are important controls of changes in soil physical properties.

\section{Soil $\rho_{b}$}

With one exception, differences in soil $\rho_{b}$ were absent at all depths. Dividing the top $10 \mathrm{~cm}$ layer into two, $5-\mathrm{cm}$ segments might affect conclusions, since soil changes typically begins near the surface. The analysis of the entire $0-10 \mathrm{~cm}$ depth could have obscured some near soil differences that might be statistically significant. The lone difference was at the Jackson site, where soil $\rho_{b}$ in the $0-10 \mathrm{~cm}$ layer was less in soil under switchgrass than under indiangrass. Both of these are perennial, warm-season grasses with similar growth habits, but it is possible that species differences in shallow rooting biomass could have caused the difference in soil $\rho_{b}$. For example, another study reported that soil $\rho_{b}$ can be less under switchgrass than that under cropland in the $0-5 \mathrm{~cm}$ layer, but equal in the $5-10 \mathrm{~cm}$ layer [17], and similarly, soil $\rho_{b}$ in the top $3 \mathrm{~cm}$ under switchgrass or trees was less than that under 
Table 4: Mean Tensile Strength (kPa) of Aggregates $(4.75-8 \mathrm{~mm})$ of the $0-10$ and $10-20 \mathrm{~cm}$ Soil Depths Under Four Crop Species at Three Sites in Ohio

\begin{tabular}{|c|c|c|}
\hline \multirow[b]{2}{*}{ Northwest } & \multicolumn{2}{|c|}{ Tensile Strength ( $\mathrm{kPa})$} \\
\hline & $0-10 \mathrm{~cm}$ & $10-20 \mathrm{~cm}$ \\
\hline Corn† & $549^{b}$ & 561 \\
\hline Switchgrass & $347^{\mathrm{a}}$ & 443 \\
\hline Willow & $410^{a b}$ & 424 \\
\hline$p$-value & 0.0360 & 0.1512 \\
\hline \multicolumn{3}{|l|}{ Western } \\
\hline Corn & $372^{b}$ & 367 \\
\hline Switchgrass & $274^{\mathrm{a}}$ & 345 \\
\hline Indiangrass & $200^{\mathrm{a}}$ & 266 \\
\hline Willow & $219^{a}$ & 259 \\
\hline$p$-value & 0.0013 & 0.1283 \\
\hline \multicolumn{3}{|l|}{ Jackson } \\
\hline Switchgrass & 193 & 202 \\
\hline Indiangrass & 224 & 238 \\
\hline$p$-value & 0.2167 & 0.3184 \\
\hline
\end{tabular}

${ }^{\dagger}$ Means with different letters within a soil depth and site are significantly different at $\mathrm{P}<0.05$.

corn [41]. Differences in $\rho_{b}$ have been observed in other crop studies, but are also often site-specific $[25,42]$.

\section{Hydrological Properties}

There were few differences in SMCs under crops at two of the three sites in Ohio. Interestingly, at the Jackson site, soils in the $0-10$ depths under switchgrass held more water than that under indiangrass at $\Phi$ between 0 and $100 \mathrm{kPa}$, and soil under switchgrass also tended to have more PAW than that under indiangrass. The soil under switchgrass also tended to have a higher $\theta$ than that under indiangrass at the Western site, but due to small sample size (only two indiangrass plots at the site), differences were not significant. This result was unexpected, as both species are perennial, warm-season grasses. Root biomass and root-shoot ratios of switchgrass are comparable or higher than those of indiangrass, and switchgrass root biomass responds more to $\mathrm{N}$ fertilization than does indiangrass [43]. The differences in soil moisture between these grasses could be a result of prior fertilization history, where switchgrass plots received $50 \mathrm{~kg} \mathrm{~N} \mathrm{ha}^{-1}$ in 2008 and 2009, while indiangrass was unfertilized.
At the Northwest site, differences in soil $\theta$ were only present at low $\Phi$ (less negative) in the 0-10 depths, where soil under corn held less water than those under switchgrass or willow. At the Western site, PAW tended to be the lowest under corn, and was significant at the $30-40 \mathrm{~cm}$ depth. The PAW has been used as a factor in productivity indices [44], and a high PAW may help stabilize yields across years and maintain yields even during droughts [45]. In addition, PAW has also been positively correlated with SOC, suggesting that soils with greater moisture storage may also store more $\mathrm{C}$ and enhance $C$ sequestration goals [46]. The slightly elevated PAW in soils under perennial grasses and trees may therefore be a result of increased root biomass that is converted into SOC. Overall, the results suggest that soil under corn may have less PAW than perennial species by either having lower $\theta$ at low $\Phi$ (i.e., at FWC) or having higher $\theta$ at PWP. However, changes in hydrological properties due to changes in bulk density and pore size distribution can take decades to occur, as a study comparing croplands with restored grasslands and native grasslands suggests [47].

\section{Aggregate Stability}

The contribution of SOM from grasses can increase WSA, MWD, and also improve soil moisture retention at low $\Phi$ (less negative) [48]. Larger root mass, root exudates, and the presence of fungal hyphae in soils under grasses and willow also improve the stability of macroaggregates [49]. Differences in WSA were only observed in one location (the Northwest site). However, these results are in accord with other studies in that perennial species had greater numbers of large aggregates than in soils under annual crops $[50,51]$.

Site-specific differences may have occurred because of differences in soil texture: the WSA of soil under corn can be lower than that under a perennial forage species for clayey soils [52], similar to the results of the present study. The conversion of pasture to cropland can gradually decrease aggregate stability, while the reverse may slowly increase it, although it may take decades for lands converted to pasture to attain the WSA and MWD of long-term grasslands [14]. Increased WSA has been associated with increased SOC, contributed from both plant roots and microbial inputs $[49,51]$. At the Western site, where the previous land use was cropland, and it is possible that conversion to perennial grasses and trees enhanced aggregate stability and that significant differences may develop in the future. In contrast, the other two sites 
were managed under perennial cover (native grasses and sod), so conversion to biofuel crops may have had less of an impact on WSA.

\section{Aggregate Tensile Strength}

The TS was the largest under corn, compared to that under grasses or willow at both sites where corn, grasses, and willow were established. The data suggest that TS is lower under switchgrass than in soil under corn. Soil penetration resistance (SPR), another measure of soil mechanical resistance, was measured to $10 \mathrm{~cm}$ at the Western site: similarly, soils under corn have greater SPR [19]. These results are in accord with those of Blanco-Canqui et al. [25], where soils under switchgrass and forest had lower TS than those under crops. Lower soil TS under switchgrass is likely due to dense and prolific root systems near the surface. Switchgrass can produce $>20 \mathrm{mg}$ roots $\mathrm{cm}^{-3}$ in the top $15 \mathrm{~cm}$ of soil [53], while NT corn root density is $<3 \mathrm{mg}$ $\mathrm{cm}^{-3}$ to the same depth [54]. An increase in SOM may improve aggregate stability and porosity, resulting in less compacted aggregates and lower soil TS.

\section{CONCLUSIONS}

While significant differences in soil $\rho_{b}, \theta$, WSA, and TS occurred only occasionally, where differences in soil properties occurred, it generally agreed with the hypothesis that soils under perennial grasses and willow would have improved soil properties compared to that under corn. It is likely that increased organic inputs in soils under perennial biofuel crops from plant roots and microbial activity may play a large role in explaining differences observed among the perennial species and the annual crop corn. Overall, there were few differences in soil physical properties among the two warm-season grasses, suggesting that both grasses are equally beneficial to soil qualities. Willow and indiangrass co-occurred only at one site (Western), making comparison of soil properties more difficult. Soil physical properties under willow and switchgrass tended to be similar, suggesting that perennial crops may enhance soil quality more than does corn. While changes in soil properties begin in the soil surface, it is possible that additional changes may occur over time in subsoil layers as well.

\section{ACKNOWLEDGEMENT}

The project is funded through a grant from US-DOE, Office of Science, Biological and Environmental Research.

\section{REFERENCES}

[1] Renewable Fuels Association. Ethanol industry statistics. [cited 2012 July 6]. Available from: http://www.ethanolrfa.org/pages/statistics

[2] Bonin CL, Lal R. Agronomic and ecological implications of biofuels. Adv Agron 2012; 117: 1-50. http://dx.doi.org/10.1016/B978-0-12-394278-4.00001-5

[3] Adler PR, Del Grosso SJ, Parton WJ. Life-cycle assessment of net greenhouse-gas flux for bioenergy cropping systems. Ecol Appl 2007; 17: 675-91.

http://dx.doi.org/10.1890/05-2018

[4] Tilman D, Hill J, Lehman C. Carbon-negative biofuels from low-input high-diversity grassland biomass. Science 2006; 314: 1598-600.

http://dx.doi.org/10.1126/science.1133306

[5] Hill J, Polasky S, Nelson E, et al. Climate change and health costs of air emissions from biofuels and gasoline. Proc Natl Acad Sci USA 2009; 106: 2077-82. http://dx.doi.org/10.1073/pnas.0812835106

[6] Boehmel C, Lewandowski I, Claupein W. Comparing annual and perennial energy cropping systems with different management intensities. Agric Syst 2008; 96: 224-36. http://dx.doi.org/10.1016/j.agsy.2007.08.004

[7] Blanco-Canqui $\mathrm{H}$. Energy crops and their implications on soil and environment. Agron J 2010; 102: 403-19. http://dx.doi.org/10.2134/agronj2009.0333

[8] Arshad MA, Martin S. Identifying critical limits for soil quality indicators in agro-ecosystems. Agric, Ecosyst Environ 2002; 88: 153-60.

http://dx.doi.org/10.1016/S0167-8809(01)00252-3

[9] Barthès $B$, Roose E. Aggregate stability as an indicator of soil susceptibility to runoff and erosion; validation at several levels. Catena 2002; 47: 133-49. http://dx.doi.org/10.1016/S0341-8162(01)00180-1

[10] Amézketa E. Soil aggregate stability: a review. Journal of Sustainable Agriculture 1999; 14: 83-151. http://dx.doi.org/10.1300/J064v14n02 08

[11] Earl HJ, Davis RF. Effect of drought stress on leaf and whole canopy radiation use efficiency and yield of maize. Agron $\mathrm{J}$ 2003; 95: 688-96.

http://dx.doi.org/10.2134/agronj2003.0688

[12] Reddy AR, Chaitanya KV, Vivekanandan M. Droughtinduced responses of photosynthesis and antioxidant metabolism in higher plants. J Plant Physiol 2004; 161: 1189202.

http://dx.doi.org/10.1016/i.jplph.2004.01.013

[13] Vörösmarty CJ, Green P, Salisbury J, Lammers RB. Global water resources: vulnerability from climate change and population growth. Science 2000; 289: 284-8.

http://dx.doi.org/10.1126/science.289.5477.284

[14] Haynes RJ, Beare MH. Aggregation and organic matter storage in meso-thermal, humid soils. In: Saxton KE, Rawls WJ, editors. Soil water characteristic estimates by texture and organic matter for hydrologic solutions Boca Raton: Lewis Publishers 2006; pp. 213-62.

[15] Johnson JM, Barbour NW, Weyers SL. Chemical composition of crop biomass impacts its decomposition. Soil Sci Soc Am J 2007; 71: 155-62. http://dx.doi.org/10.2136/sssaj2005.0419

[16] Vinton MA, Burke IC. Interactions between individual plant species and soil nutrient status in shortgrass steppe. Ecology 1995; 76: 1116-33. http://dx.doi.org/10.2307/1940920

[17] Liebig MA, Johnson HA, Hanson JD, Frank AB. Soil carbon under switchgrass stands and cultivated cropland. Biomass Bioenergy 2005; 28: 347-54.

http://dx.doi.org/10.1016/j.biombioe.2004.11.004 
[18] Evrendilek F, Celik I, Kilic S. Changes in soil organic carbon and other physical soil properties along adjacent Mediterranean forest, grassland, and cropland ecosystems in Turkey. J Arid Environ 2004; 59: 743-52.

http://dx.doi.org/10.1016/j.jaridenv.2004.03.002

[19] Bonin C, Lal R, Schmitz M, Wullschleger S. Soil physical and hydrological properties under three biofuel crops in Ohio. Acta Agric Scand, Sect B 2012; 62: 595-603.

[20] Ma Z, Wood CW, Bransby DI. Soil management impacts on soil carbon sequestration by switchgrass. Biomass Bioenergy 2000; 18: 469-77.

http://dx.doi.org/10.1016/S0961-9534(00)00013-1

[21] Follett RF, Vogel KP, Varvel GE, Mitchell RB, Kimble J. Soil carbon sequestration by switchgrass and no-till maize grown for bioenergy. Bioenergy Res 2012. http://dx.doi.org/10.1007/s12155-012-9198-y

[22] Frank A, Berdahl J, Hanson J, Liebig M, Johnson H. Biomass and carbon partitioning in switchgrass. Crop Sci 2004; 44: 1391-6.

http://dx.doi.org/10.2135/cropsci2004.1391

[23] Tufekcioglu A, Raich JW, Isenhart TM, Schultz RC. Biomass, carbon and nitrogen dynamics of multi-species riparian buffers within an agricultural watershed in lowa, USA. Agrofor Syst 2003; 57: 187-98.

http://dx.doi.org/10.1023/A:1024898615284

[24] Seobi T, Anderson SH, Udawatta RP, Gantzer CJ. Influence of grass and agroforestry buffer strips on soil hydraulic properties for an albaqualf. Soil Sci Soc Am J 2005; 69: 893901. http://dx.doi.org/10.2136/sssaj2004.0280

[25] Blanco-Canqui H, Lal R, Lemus R. Soil aggregate properties and organic carbon for switchgrass and traditional agricultural systems in the southeastern United States. Soil Sci 2005; 170: 998-1012. http://dx.doi.org/10.1097/01.ss.0000187342.07331.a6

[26] Soil Survey Staff, Natural Resources Conservation Service. United States Department of Agriculture. Official soil series descriptions. [cited 2012 June 22]. Available from: http://soils.usda.gov/technical/classification/osd/index.html

[27] USDA-NRCS. Web soil survey. [cited 2012 June 22]. Available from: http://websoilsurvey.nrcs.usda.gov/app/ HomePage.htm

[28] Jung JY. Nitrogen fertilization impacts on soil organic carbon and structural properties under switchgrass. PhD dissertation. Columbus: The Ohio State University; 2010.

[29] Grossman RB, Reinsch TG. Bulk density and linear extensibility. In: Dane JH, Topp GC, Eds. Methods of soil analysis Part 4. Madison: SSSA 2002; pp. 201-25.

[30] Klute A, Dirksen C. Hydraulic conductivity and diffusivity: laboratory methods. In: Klute A, Ed. Methods of soil analysis Part 1: Physical and mineralogical methods. 2nd. ed. Madison: ASA-SSSA 1986; pp. 687-734.

[31] Brady NC, Weil RR. The nature and properties of soils. $13^{\text {th }}$ ed. Upper Saddle River: Prentice Hall 2001.

[32] Yoder RE. A direct method of aggregate analysis of soils and a study of the physical nature of erosion losses. J Am Soc Agron 1936; 28: 335-7.

http://dx.doi.org/10.2134/agronj1936.0002196200280005000 $\underline{1 \mathrm{x}}$

[33] Kemper WD, Rosenau RC. Aggregate stability and size distribution. In: Klute A, Ed. Methods of soil analysis, Part 1: Physical and mineralogical methods. 2nd ed. Madison: ASASSSA 1986; pp. 425-42.

[34] Youker RE, McGuinness JL. A short method of obtaining mean weight-diameter values of aggregate analyses of soils. Soil Sci 1957; 83: 291-4.

http://dx.doi.org/10.1097/00010694-195704000-00004
[35] Horn R, Dexter AR. Dynamics of soil aggregation in an irrigated desert loess. Soil Tillage Res 1989; 13: 253-66. http://dx.doi.org/10.1016/0167-1987(89)90002-0

[36] Dexter AR, Kroesbergen B. Methodology for determination of tensile strength of soil aggregates. J Agric Eng Res 1985; 31: 139-47. http://dx.doi.org/10.1016/0021-8634(85)90066-6

[37] Rogowski AS, Moldenhauer WC, Kirkham D. Rupture parameters of soil aggregates. Soil Sci Soc Am J 1968; 32: 720-4. http://dx.doi.org/10.2136/sssaj1968.03615995003200050037 $\underline{x}$

[38] Burt R, Ed. Soil survey laboratory methods manual. Version 4.0. Soil survey investigations report No. 42. Washington: USDA-NRCS 2004.

[39] SAS. SAS user's guide: Statistics. Cary: SAS Institute 2009.

[40] Carter MR. Researching structural complexity in agricultural soils. Soil Tillage Res 2004; 79: 1-6.

http://dx.doi.org/10.1016/j.still.2004.04.001

[41] Tolbert V, Todd D, Mann L, et al. Changes in soil quality and below-ground carbon storage with conversion of traditional agricultural crop lands to bioenergy crop production. Environ Pollut 2002; 116: S97-S106.

http://dx.doi.org/10.1016/S0269-7491(01)00262-7

[42] Coleman MD, Isebrands JG, Tolsted DN, Tolbert VR. Comparing soil carbon of short rotation poplar plantations with agricultural crops and woodlots in North Central United States. Environ Manage 2004; 33: S299-308. http://dx.doi.org/10.1007/s00267-003-9139-9

[43] Heggenstaller AH, Moore KJ, Liebman M, Anex RP. Nitrogen influences biomass and nutrient partitioning by perennial, warm-season grasses. Agron J 2009; 101: 1363-71.

http://dx.doi.org/10.2134/agronj2008.0225x

[44] Pierce FJ, Dowdy RH, Larson WE, Graham WAP. Soil productivity in the Corn Belt: An assessment of erosion's long-term effects. J Soil Water Conserv 1984; 39: 131-6.

[45] Morgan CLS, Norman JM, Lowery B. Estimating plantavailable water across a field with an inverse yield model. Soil Sci Soc Am J 2003; 67: 620-9. http://dx.doi.org/10.2136/sssaj2003.0620

[46] Lal R. Enhancing crop yields in the developing countries through restoration of the soil organic carbon pool in agricultural lands. Land Degrad Dev 2006; 17: 197-209. http://dx.doi.org/10.1002//dr.696

[47] Schwartz R, Evett S, Unger P. Soil hydraulic properties of cropland compared with reestablished and native grassland. Geoderma 2003; 116: 47-60. http://dx.doi.org/10.1016/S0016-7061(03)00093-4

[48] Ekwue El. Organic-matter effects on soil strength properties. Soil Tillage Res 1990; 16: 289-97.

http://dx.doi.org/10.1016/0167-1987(90)90102-J

[49] Tisdall JM, Oades JM. Organic matter and water-stable aggregates in soils. J Soil Sci 1982; 33: 141-63. http://dx.doi.org/10.1111/j.1365-2389.1982.tb01755.x

[50] Udawatta RP, Kremer RJ, Adamson BW, Anderson SH. Variations in soil aggregate stability and enzyme activities in a temperate agroforestry practice. Appl Soil Ecol 2008; 39: 153-60. http://dx.doi.org/10.1016/..apsoil.2007.12.002

[51] Kremer RJ, Li J. Developing weed-suppressive soils through improved soil quality management. Soil Tillage Res 2003; 72 : 193-202.

http://dx.doi.org/10.1016/S0167-1987(03)00088-6

[52] Angers DA. Changes in soil aggregation and organic carbon under corn and alfalfa. Soil Sci Soc Am J 1992; 56: 1244-9. http://dx.doi.org/10.2136/sssaj1992.03615995005600040039 $\underline{x}$ 
[53] Ma Z, Wood CW, Bransby DI. Impacts of soil management on root characteristics of switchgrass. Biomass Bioenergy 2000; 18: 105-12. http://dx.doi.org/10.1016/S0961-9534(99)00076-8
[54] Barber SA. Effect of tillage practice on corn (Zea mays L.) root distribution and morphology. Agron J 1971; 63: 724-6. http://dx.doi.org/10.2134/agronj1971.0002196200630005002 $\underline{\underline{0 x}}$

Received on 27-07-2012

DOI: http://dx.doi.org/10.6000/1929-6002.2012.01.01.1

(C) 2012 Bonin and Lal; Licensee Lifescience Global.

This is an open access article licensed under the terms of the Creative Commons Attribution Non-Commercial License (http://creativecommons.org/licenses/by-nc/3.0/) which permits unrestricted, non-commercial use, distribution and reproduction in any medium, provided the work is properly cited. 